FOLIA SCANDINAVICA VOL. 20 POZNAŃ 2016 DOI: $10.1515 / \mathrm{fsp}-2016-0029$

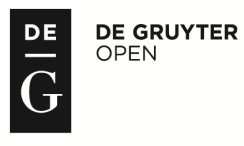

PRESSTO.

\title{
TIL LYKKE
}

\author{
PIA JARVAD
}

Dansk Sprognavn

ABSTRACT. In this article I give semantic and historical explanations of some selected lexical areas that may cause problems for non-native speakers of Danish. I describe some important developments in a historical perspective, showing how new words shift the semantics of old words. I also deal with how many new words are continuously recorded and the vast majority of new words are occasional formations. They show the creativity in Danish language. I have selected two new words from each year since 1946 to honor the 70-year-old professor in Danish.

Til lykke til en professor i dansk, som fylder 70 år og som fortjener hæder og ære for sin indsats for dansk sprog og kultur her. Til lykke skal det lyde sammen med en tak for et godt samarbejde fra Dansk Sprognævn og fra mig. I min artikel til professoren har jeg i det følgende fokuseret på en række mindre områder som i særlig grad kan volde problemer for den dygtige dansktalende som dog ikke har modersmålskompetence.

\section{FITNESS}

Det forekommer mig at fitness ikke har været Geneks spidskompetence, ej heller været blandt hans ambitioner. Derfor skal han have nogle ord med fra denne verden, ord som alle afspejler de ændringer på synet af legemsøvelser som er karakteristisk for de sidste 70 år.

Selve ordet legemsфvelse er beskrevet i Ordbog over det Danske Sprog (herefter $O D S$ ) som 'legemlig virksomhed, som kan udvikle legemets sundhed, styrke, smidighed olgn.; sportsøvelse; gymnastik'. If $\varnothing$ lge ordbogen er ordet fra o. 1700-tallet, og det bruges om især tilrettelagte legemsøvelser. Således hed mit skolefag legemsøvelser i slutningen af 1950'erne indtil det i 1960'erne blev afløst af ordet gymnastik. Sidenhen blev skolefaget omdøbt til idræt. 
Ordet kondition er gammelt i dansk, men dog med betydninger som 'vilkår', 'omstændigheder', mens den sportive betydning angiver $O D S$ (bind $10,1928)$ som et betydningslån fra engelsk om 'den af træning osv. betingede skikkethed til at deltage i en kamp olgn.; især i forb. som i (god) kondition, ude af kondition'. ODS giver et citat:

(1) den kødfulde Bokser, der staar oprejst i Ringen i fineste Kondition, ved fuld Kraftbevidsthed. (Johannes V. Jensen: Digte, 1906)

Forkortelsen kondi registreres første gang i 1958 if. Nye Ord i Dansk - fra 1955 til i dag (herefter NOiD), og der opstår efterfølgende et væld af sammensætninger med kondi- som førsteled, fx kondisko, kondicykel. Fitnessen løbes langsomt i gang i 1960'erne, men i den periode har den unge generation travlt med så meget andet: studenteroprør, pot, gruppesex, storfamilie mv., så udvalget er endnu sparsomt: circuittraning, ergometercykel, sweeper, motionscykel, er hvad man kan byde på i NOiD, som også har disse med fra senere perioder:

1970'erne: motionscenter, coach

1980'erne: aerobic, mountainbike, fitness, vandgymnastik

1990'erne: akvaaerobic, motionsvideo, akvarytmik, hydropower 'art vandgymnastik', spinning, bodybike d.s.s. kondicykel, wellness

2000'erne: bodyfitness, stripfitness, akvaspinning, parkour 'springe fra et sted til et andet', lattercoach, polefitness 'fitness omkring en stripperstang', crossfit, zumba 'kombination af aerobic og dans'

2010'erne: boxjump 'hopning fra gulv til lav kasse', crossfitte 'at dyrke crossfit', gun 'muskuløs overarm', helseskov.

\section{LIVLINE}

Nogle ord og udtryk er ikke til at forstå umiddelbart, også selv om man kan gennemskue de led som ordet består af. Hustag er 'taget på et hus', førsteled er det led som kommer først osv. Lars Brink kalder betydningen af det umiddelbart forståelige ord for dets pålydendeværdi ${ }^{1}$, en betegnelse som jeg tager til mig her. Det er gængs at pålydendeværdien som et ord har, er den primære, og herefter kan der opstå en overført betydning, en billedlig brug osv. Det er fx den faste rækkefølge i en ordbog når betydningerne oplistes. Men der er ord hvor en pålydendeværdi ikke er eksisterende, fx huskekage som er et lidt gammeldags ord for 'lussing, lærestreg'. Stor var så min overraskelse at se dette opslag i mit lokale distriktsblad Nordsjaelland:

\footnotetext{
${ }^{1}$ Personlig kommunikation.
} 
(2) Huskekage

På landets plejecentre fejres den internationale Altzheimersdag 21.9.2015 som en huskedag for demente og med kaffe og kage, og i den forbindelse opfordres pårørende og medarbejdere til at bage og sælge såkaldte "huskekager".

En huskekage er et stærkt leksikaliseret ord som her bliver afleksikaliseret og skal forstås ved dets pålydendeværdi som 'kage der får en til at huske'.

Et andet ord er torskegilde som betegner et 'møde, hvortil skattevæsenet tilkalder skatteydere, hvis selvangivelse ikke anerkendes' (ODS). Samme ordbog oplyser ikke noget om hvorfor det hedder sådan, men en mulig forklaring kan være at skæringsdatoen for regnskabsåret er 31/12, det vil sige nytårsaften, hvor der traditionelt serveres torsk i Danmark. I Den Danske Ordbog (herefter DDO) har torskegilde én betydning, nemlig den leksikaliserede: 'møde hvortil skattevæsenet indkalder en skatteyder hvis man ikke kan acceptere den pågældende persons selvangivelse'. Nu er det dog ikke sådan at $D D O$ kun medtager leksikaliserede sammensætninger og udelader de gennemsigtige, jf. fx at baconstykke er med betydningen 'et stykke bacon'. Men $D D O$ adskiller sig her fra $O D S$ som også har pålydendeværdien for ordet: 'selskabelig sammenkomst, gilde, hvor der serveres (kogt) torsk'. Man kunne fristes til at tro at pålydendeværdien af torskegilde i ODS er kommet med af systemtvang.

Ordet livline har pålydendeværdien 'tov der er fastgjort til en person som en sikkerhedsforanstaltning fx i forbindelse med arbejde eller sportsudøvelse hvor der er fare for at falde ned'. Den overførte betydning 'mulighed for at få hjælp i en ellers vanskelig situation' er dog langt mere i brug i dag. I et meget populært quizprogram får deltagerne 3 livliner som kan benyttes hvis de er i tvivl om svaret, dvs. at få hjælp på 3 forskellige måder.

Krydderen galt $i$ halsen er et moderne udtryk for at blive meget overrasket, man kan godt fundere over at det dannes nu når man betænker at krydderen som morgenbrød ikke mere er særligt almindeligt. På samme måde er ordet badebillet eller især i forbindelsen komme med på en badebillet ikke umiddelbart gennemskuelig; det betyder 'letkøbt eller ufortjent adgang til noget eftertragtet', som i dette citat fra $D D O$ :

(3) Danmark får badebillet til VM. Det danske kvindelandshold får en let start på VM i Brasilien i december

En mulig forklaring på den overførte brug kunne være at uleksikaliserede badebilletter ikke er kostbare.

\section{LAPS}

Laps er med i NOiD med ældste belæg fra 1990. Den nye brug er 'sjusket mand'; den gamle betydning er det modsatte, nemlig: 'pyntet mand'; tøjjon, dandy. DDO og Den Danske Netordbog (DDN) har begge de to betydninger 
og fordelt på samme måde. $D D O$ tilføjer at den nye brug om 'lurvet og sjusket klædt (yngre) mand' regnes af mange for ukorrekt. $O D S$ angiver etymologien til ordet og angiver den ældste betydning: 'ung, næsvis, uopdragen, drengeagtig mandsperson 'levemand' med flabet væsen'; 'fræk pigejæger'. Ordet pendulerer således fra flabet levemand over dandy til sjuske.

\section{YMER}

Ymer er den jætte som i den nordiske mytologi drak mælken fra koen Audhumbla. Ymer er også et syrnet tyktflydende mælkeprodukt. Og så indgår det vistnok i datidens slangudtryk: fed ymer, bred ymer 'alle tiders' fra midthalvfjerdserne, Geneks og min ungdomstid. I NOiD er der 3 eksempler på udtrykket, de to er metaeksempler, der handler om ordet, det tredje næsten et rigtigt citat fra Politiken, 28.8.1981:

(4) Post til tiden, som skolebørnenes sprognævn nu siger, hvis noget fortjener ros. Bred ymer og færdigt arbejde er så forældede som en politiker på visit i TVavisen.

Eva Skafte Jensen (2014a; 2014b; 2014c) sætter spørgsmålstegn ved om det var et udtryk som blev aktivt brugt (det samme siger hun om knahøj karse), hun tvivler. Det gør jeg også og tilføjer et andet ord som også i eftertiden er sat til at karakterisere perioden: bollerum 'rum til at dyrke sex i'. Det kommer med i NOiD, først i 2015, med ældste "rigtige" citat fra 1978. Eftertiden har tillagt perioden mangt og meget, sågar ord.

\section{KREATIVITET OG NYE ORD}

Dannelse af nye ord er sprogets kreativitet. Nogle af de nye ord afspejler den verden som er nu. Nogle af dem er benævnelser for nye ting og fænomener, fx udsatteråd 'kommunalt råd for varetagelse af udsattes (fx hjemløse) tarv', grønvask 'det at varer o.l. fremstår som mere $\varnothing$ kologiske og klimavenlige end de i realiteten er', maelkeskandale (om skandale i Kina hvor der blev tilsat melamin i mælken med skrækkelige sundhedsmæssige konsekvenser).

Andre nye ord dannes for noget som kendes i forvejen, fx liebhaverbolig (luksusbolig), klatfravar (pjækkedag) og sundhedskort (sygesikringskort), og disse ord udtrykker ofte holdninger til fænomenet. Gamle ord får tillagt nye betydninger, fx kant og underfrankeret, og når haenger $\phi v$ bliver brugt om personer. Til nye ord regnes også at ordet bruges på en ny måde, fx dumpe eksamen hvor det traditionelle er dumpe til eksamen eller tanke sommerferie i stedet for tanke på sommerferie. Udtryk som boliggaranti ver. 2.0, uhellig alliance har, selvom de består af to ord, som helhed en fast betydning og fast form, og de er således nye faste udtryk, og de hører med i beskrivelsen af nye ord. 
Når et nyt ord opstår, ved man aldrig om ordet bliver et varigt tilskud til dansk eller om det forsvinder lige så hurtigt som det kom. Forsvinde hurtigt gjorde burkaudvalg 'udvalg som skulle tage stilling til brug af burka i det offentlige rum', og klimakaravane 'bus som kørte rundt i landet i 2008-9 med oplysning om den globale opvarmnings betydning for klimaet'. Sådanne kometord (Jarvad, 1995:173) har stærk affinitet til bestemte hændelser og kan ikke forstås uden at man kender til hændelserne. De har potentiale til at blive varige tilskud til vores ordforråd, men det finder man først ud af når der er gået et stykke tid, og fænomenet er blevet et fast og varigt fænomen.

En anden type nye ord som ikke får varig indflydelse på sproget, er de banale sammensætninger, fx klimakonference, klageantal, vaerdipapirsammensatning, risikoappetit. De er dannet af sprogets byggeklodser efter de regler som vi opbygger et ord på, og de er gennemskuelige, og uproblematiske at forstå hvis man kender førsteled og andetled. De har potentiale til at blive varige tilskud, men det finder man først ud af når der er gået et stykke tid, og ordet lægger sig fast som "ordet for tingen".

I Dansk Sprognævn har en kollega til mig, Jakob Halskov, udviklet en automatisk nyordsfinder. Programmet hedder Ordtrawleren, og med den kan man gennemtrawle kæmpestore tekstmængder for at finde de nye ord automatisk. Nye ord er så ord som ikke er fundet før, ikke står i ordbøger som Retskrivningsordbogen (RO, 1996) og DDO og heller ikke er fundet af os selv i Sprognævnet. Her er den menneskelige erfaring for nye ord, om jeg så må sige, slået fra. I tal kan vi konstatere at der er en voldsom kreativitet. Ordtrawleren læser sig måned for måned gennem avisdatabasen Infomedias tekstkorpus og registrerer tusinder af ukendte ordformer i nyhedsartiklerne. Det gør den også selvom man fjerner ca. 1,2 millioner ordformer som allerede kendes fra ordbøger og andre referenceværker og ser bort fra ord som består af grafisk tegn, fx e-mailadresser og navne. Selv efter 20 måneder observerer programmet stadig mellem fire og fem ukendte ordformer per 1000 løbende ord. En enkelt måneds data fra Infomedia (ca. 7 mio. løbende ord) bidrager således med ikke mindre end 20.000 nye ord.

En ordbogsredaktør vil naturligvis aldrig betragte mere end en brøkdel af disse ord som sproglige nydannelser der kan indgå i fx en nyordsordbog, og alle disse nydannede ord er ikke stave- eller slåfejl. De er derimod tilfældige nydannelser, ord som vi danner i samme øjeblik som vi har brug for dem. Vi danner dem efter det orddannelsesmønster som vi kender, når vi kan modersmålet. Det er 20.000 nye ord om måneden af denne type: bonuspotentiale, efterårsmadvin, fodboldekspert, forårsprognose, havnepulje, kammermusikudgivelse, pizzabande, terrormanual, vandfinale, ablefest, abbleparadis. Prøv at se på disse ord, lige til at lave: tefest (jf. det almindelige vinfest), tetallerken (jf. kagetallerken), tesфster (jf. kaffesфster), tetår (jf. kaffetår). Selv om disse te-ord ikke er med i ordbøger o.l. er de ikke nye ord i vores forstand, de kan 
dannes umiddelbart, og det er mere eller mindre tilfældigt om de er dannet og skrevet og kommet med i store tekstkorpusser.

Desuden er fx ord som maelkeskandale og ablefest som kom ud som nye ord i bestemte år, slet ikke mulige at tidsbestemme nærmere. Hvis der havde været en malkeskandale i 1930, måtte det hedde maelkeskandale, og så var ordet fra 1930. 1. maj og dagene deromkring var fløjteaktion, fløjteaktionist og fløjtenist i ny betydning, de blev også brugt ved 1. maj-arrangement i 2014, en aktion mod statsminister Helle Thorning-Schmidts tale for at overdøve den med fløjten og dermed udtrykke modstand mod den førte politik. Ordene er nu forsvundet igen.

Moderne sprogteknologi finder ikke nye ord til brug for ordbøger, men dokumenterer derimod at dansk er et rigt sprog, smidigt til at danne nye ord når vi har brug for det, og med lige så mange ord som alle andre sprog. Den folkelige forestilling om at engelsk har langt flere ord end dansk kan skrottes. Det er ikke så dumt.

\section{KAFFE}

Det er ikke få kopper kaffe jeg har nydt som gæsteforelæser i Poznań. Stærke og gode. Dem siger jeg tak for, men udtrykket tak for kaffe har en hel anden betydning end i denne kontekst. I NOiD er den nye betydning med, og betydningen er om noget man tager afstand fra: 'vorherrebevares'. Tak for kaffe er fra 1993. Etymologien til den brune drik, som den kaldes med en rædsom floskel, er i dansk via fransk café eller tysk Kaffee fra tyrkisk kahve 'kaffe', af arabisk qahwa 'kaffe, vin'. I dag er der mange slags kaffe, fx kaffe på italiensk: americano (1998) 'espresso fortyndet med kogende vand', espresso (1953), cappuccino (1962) 'lige dele espresso og varm mælk med mælkeskum og med kakaopulverdrys på toppen', caffe latte (1992) 'en del espresso tilsat to dele varm mælk og et lag mælkeskum, ofte serveret i et højt glas', latte (1998) er en kortform af caffe latte, mens café au lait (1878) er fra fransk og er lavet som caffe latte. Cortado (o. 1995, fra spansk) er 'en del espresso og en del varm mælk', mens caffé macchiato (o. 1995, italiensk igen) er 'espresso med lidt mælkeskum', mokka (medio 1800) 'stærk kaffe i små kopper', oprindeligt en syrlig, bitter arabisk kaffe udskibet fra byen Mokka i Yemen, jordemoderkaffe 'stærk kaffe' (1937), oprindelig den kaffe en jordemoder drak mens hun ventede på at en fødsel skulle gå i gang.

Kaffen er blevet lavet på mange måder: i en madam blå 'blåemaljeret kaffekedel', (1928 if. ODS.S), i en kaffekolbe (1940), i en kaffemaskine (1968), af pulverkaffe (1950), fx af mærket Neskaffe (1957), filterkaffe (hvor kaffen filtreres med et papirfilter, 1991), og i en stempelkande (1988) laves stempelkaffe (1993). Kaffen kan tilsættes andet end mælk, fx whisky eller is: irish coffee (1972), iskaffe (1947). Kaffekulturen er beriget med en barista 
'kaffemager, kaffebartender' (1999) som fx i en kaffebar (o. 2000) kan tilbyde et bredt udvalg af kaffesorter og kaffeanretninger. Den gamle brug af ordet kaffebar var om et ydmygt sted med kaffeservering, ingen alkoholservering, men med mulighed for et let måltid og hvor der typisk var åbent mellem 6 og 14 med tanke på betjening af håndværkere.

Ordet coffee table-bog (1988) eller i helt fordansket form kaffebordsbog (1992) er bøger som lægges frem fx på sofabordet til at bladre i for gæster og for at vise hvem man er. Bøgerne er gerne meget smukke, store og uhåndterlige.

\section{PENDULORD}

Pendulord er ord med to betydninger der er hinandens modsætninger. Betydningen svinger fra den ene ende af pendulet til den anden. Her er et par stykker af dem:

Bjørnetjeneste er sammen med godt (se nedenfor) de to mest omtalte pendulord. Bjørnetjeneste er med i NOiD med ældste belæg fra 1992 med betydningen 'god tjeneste'; den ældre brug er: 'velment, men malplaceret tjeneste'. Den gamle betydning refererer til La Fontaines fabel om bjørnen, der med en sten ville jage en flue væk fra sin sovende herres ansigt, men knuser hans pande. Den nye betydning synes at være opstået ved en association til teddybjørnen som den store, gode bamse. Den nye betydning af bjørnetjeneste er blevet et ikon for det danske sprogs forfald, sædernes opløsning og almindelig utilfredshed med den unge generation. For pendulord skiller normalt den gamle generation fra den unge. Men der kan nu være tvivl om hvorvidt den nye betydning af bjørnetjeneste er særlig almindelig, eller for den sags skyld også den gamle betydning; søger man i tekstkorpora er de fleste eksempler netop diskussionen om betydningen.

Forfordele er med i NOiD med ældste belæg fra 1964. Den nye betydning er 'give fordel'; 'begunstige eller favorisere', mens den sædvanlige betydning er det modsatte, nemlig: 'behandle dårligere'; 'forurette'.

Genistreg er med i NOiD med ældste belæg fra 1978. Den nye brug er pålydendeværdien, helt uden ironi, og den betyder 'opfindsom eller begavet handling', mens den gamle betydning er den ironiske brug om en dum og tåbelig optræden. Men om dette ords betydning er de lærde uenige. NOiD forudsætter betydningen 'dum og tåbelig optræden' ved at kalde den pålydendeværdi 'opfindsom eller begavet handling' for ny brug. $D D O$ har kun én betydning: 'handling, idé el.lign. der vidner om ophavsmandens geni', mens $O D S$ har tre betydninger i denne rækkefølge: 1) opfindsom handling, der vidner om begavelse, altså den pålydende brug, den der er beskrevet i NOiD: 2) også om ubesindig, dumdristig, forsoren optræden, der skal vise, at vedkommende er ubekymret om (føler sig hævet over) almindelig skik og brug, de borgerlige love osv., 3) nu især (ironisk) om dum, tåbelig optræden som er den 
der i NOiD er beskrevet som gammel brug. Det pågældende bind er fra 1924. Meyers Fremmedordbog fra 1924 skriver at genistreg mest bruges i misbilligende forstand for: 'vrang, urimelig Streg'. Det kunne tyde på at ordet svinger frem og tilbage flere gange.

Godt er med i NOiD med ældste belæg fra 1961. Den nye betydning er 'lidt mindre end'; den traditionelle betydning er 'lidt mere end'. For mig der falder mellem to stole i netop dette ord, har det været en huskeregel at jævnføre med knap: knap klokken 12 er før klokken 12; men nu er knap også et pendulord: ny betydning er 'lidt over'; den traditionelle betydning er 'lidt under'. Så skal vi mødes knap eller godt 12, kære Genek; vi må vist hellere sige klokken præcis 12 .

\section{MED 70 (X 2) DANSKE ORD TIL EUGENIUZ RAJNIK}

I 1946 hvor Eugeniusz Rajnik blev født, blev der for første gang registreret ordene chokolademalk, fifty-fifty, gangstervaelde, gentleman agreement, husmorservice, iblфdsæetningsmiddel, isshow, kernekemi, korridorhus, løgn og lakrids 'vås', levende lys, ligge lunt $i$ svinget, ikke forstå eller fatte en lyd, pindemad, pullimut 'dårlig vin', rhesusfaktor, safaristol, seriebog, social forsorg, rejse på tommelfingeren, velskanket $\phi l$. Ordene afspejler det danske samfund lige efter krigen, ordene peger fremad mod det som i 1955 kaldes velfardssamfund. I det følgende er der som en snas ('lille bid', 1995) fra hvert år siden Eugeniusz Rajniks fødsel:

1947: charmetrold, kuglepen

1948: atomkraft, swimmingpool

1949: bikini, kibbutz

1950: gastelarer, shoppe

1951: inddamningspolitik, teenager

1952: holdarbejde, twill

1953: børnelokker, hamburger

1954: barepose, parkacoat

1955: buksestrømper, velfardssamfund

1956: kernefamilie, rock'n'roll

1957: disinformation, køkkenelement

1958: babydoll, lordagsfri

1959: campingbil, rumsonde

1960: grøn bølge, komme hinanden ved

1961: kommunikationssatellit, landskabsplanlagning

1962: dørmand, fritidshus

1963: papmoelk, фrehaenger

1964: affaldspose, sølvbryllupskvarter 
1965: flue på vaggen, kropsnoer

1966: flippe, komme ind fra kulden

1967: abortrejse, flowerpower

1968: generationskløft, hyrdetoppe

1969: biovask, fingermaling

1970: bofalle, galar

1971: edb-assistent, klassens time

1972: diskette, dragshow

1973: afrorock, vådområde

1974: jogging, wok

1975: mandelejr, weekendfar

1976: burhøne, musefaeldeklausul

1977: bistandshjoelp, skuffeselskab

1978: følsom oplysning, stjernekrig

1979: astmadyne, prastestyre

1980: halal, varmluftsovn

1981: foodprocessor, seksuel chikane

1982: boulespil, lørdagskylling

1983: aerobic, kostfiber

1984: bulgur, bypassoperation

1985: aids-virus, ålefarm

1986: asylant, pyramidespil

1987: gadefodbold, middelhavskøkken

1988: blå flag-havn, standupkomiker

1989: fatwa, pc-virus

1990: cyberpunk, kogalskab

1991: affaldssortering, ozonhul

1992: affaldsturisme, plug and play

1993: internet, фstkriminalitet

1994: EU-borger, www

1995: lookalike, snailmail

1996: demensklinik, forandringsparat

1997: cigarbar, rygerlunge

1998: drabersnegl, tovholder

1999: bamsevin 'vin med højt alkoholindhold', trivselsdag

2000: blog 'netdagbog', keglet 'kikset'

2001: alfahan 'dominerende mand i en gruppe', faktatjek 'undersøgelse af om noget passer'

2002: kulturmuslimsk, babysalmesang

2003: macaron, doktorfisk 'lille fisk som renser fødder for hård hud som den spiser'

2004: cutter 'person som skærer i sig selv pga. psykiske vanskeligheder', trainsurfe 
2005: arabisk forår, hjemmerøveri

2006: liggedag 'dag hvor beboerne på et plejehjem må blive i sengen', $\phi v d a g$

2007: cloudcomputing 'det at bruge programmer på nettet', $e$-cigaret

2008: bandepoliti, naese-til-hale- 'det at udnytte kødet fra dyrets næse til dens hale'

2009: bygotto 'risotto med byg i stedet for ris', hashtag 'emneord for tweets som handler om det samme'

2010: crave 'have trang til', fail 'fejl'

2011: bitcoin 'møntenhed i digital valuta', fremmedkriger 'person som tager til fremmed land for at deltage i en krig'

2012: smartur, brexit 'britisk udtræden af EU'

2013: selfie 'selvportræt taget med mobiltelefon og lagt ud på de sociale medier', $e$-damp 'damp fra e-cigaret'

2014: tys-tys-kilde 'hemmelig kilde i journalistik', skraldetragt 'skraldespand med stor åbning som er placeret i en bils vindueshøjde'.

2015: je suis Charlie, segboard 'art rullebræt med motor'

2016: skattelaek også kaldet luxleak 'en læk med oplysninger om skattely for fremtrædende personer via bank i Panama'

\section{0. ÅRETS ORD}

Årets ord er en genre som begyndte at dukke op for knap 10 år siden. Inspirationen til dette kom fra tysksprogede lande som Tyskland, Østrig, Schweiz som i en årrække har haft udvælgelser af årets ord og udtryk. På tysk udkom en ordbog over århundredets "kerneord", ord som år for år karakteriserede netop dette år, fx atombombe (1945), kreditkort (sluttresserne), fastfood (1971), nylonstrømpe (sluttrediverne) (Krone/Walther, 2001). Selv om bogen beskriver tyske forhold, er der, som eksemplerne viser, stor lighed med danske forhold. 2000-årets nye ord (eller ord som er slået igennem i 2000) er fx disse tyske ord i dansk udgave: BSE-krise (BSE-Krise), greencard (Greencard), sms (SMS), kamphund (Kampfhund), bigbrotherhus (Big-Brother-Haus).

Først herhjemme var sprogtidsskriftet Mål \& Mæle i 2006, som det kan ses nedenfor. Mange ord er blevet kåret, både gamle ord (fx lømmelpakke af Mål \& Male og DRs Sproglaboratoriet i 2009, men det er i hvert fald fra 2000), og helt nye (fx akutjob af Mål \& Maele i 2012), og ord som forsvandt lige så hurtigt som de dukkede op (fx vuvuzela af både Mål \& Mcele og DR i 2000). Fælles for arrangørerne af kåringerne har været at årets ord ikke nødvendigvis skulle være nye ord, men derimod være fremtrædende i året. Der er også et $\emptyset$ nske om at hovedbidragyderne til forslagene skulle være i Mål og Males tilfælde læserne, hos DR lytterne. For Mål \& Male var dommerne redaktørerne, altså fagfolk, mens det for DRs vedkommende repræsentanter for medierne, 
sprogprogrammet Sproglaboratoriet og Dansk Sprognævns direktør. I den norske liste er forslagene menige nordmænd, mens dommerne definerede bestemte kriterier for udvælgelsen og det endelige ord.

\begin{tabular}{|c|c|c|c|c|}
\hline & $\begin{array}{c}M \& M \\
\text { ÅRETS ORD }\end{array}$ & $\begin{array}{c}M \& M \\
\text { ÅRETS } \\
\text { VENDING }\end{array}$ & $\begin{array}{c}\text { DR1, } \\
\text { SPROGLABORATORIET }\end{array}$ & $\begin{array}{c}\text { NORSK } \\
\text { SPRÅKRÅD }\end{array}$ \\
\hline 2006 & Ommer & & & \\
\hline 2007 & klimaministerium & varme hænder & & \\
\hline 2008 & udlændingeservice & $\begin{array}{l}\text { Ritts billige } \\
\text { boliger }\end{array}$ & & finanskrise \\
\hline 2009 & Lømmelpakke & jo, vi kan & Lømmelpakke & svineinfluenza \\
\hline 2010 & Askeramt & & Vuvuzela & oksefast/askefast \\
\hline 2011 & arabisk forår & & arabisk forår & $\operatorname{rosetog}^{2}$ \\
\hline 2012 & Akutjob & & Stenalderkost & å nave (naving) ${ }^{3}$ \\
\hline 2013 & - & - & Undskyld & sakte-tv ${ }^{4}$ \\
\hline 2014 & - & - & MobilePay & $\begin{array}{l}\text { framandkrigar/ } \\
\text { fremmedkriger }\end{array}$ \\
\hline
\end{tabular}

(Tab. 1) Oversigt over årets ord/vendinger i årene 2006-2014

Blandt årets ord og årets nye ord er der påfaldende lidt negativitet overfor engelske ord, noget som der ellers ofte er. $17 \%$ af de foreslåede ord er lånt fra engelsk, og i forhold til antallet af ord i ordforrådet som helhed er det ganske mange idet man regner med at der er 2,5 \% (som i $N D O$ ), mens der i forhold til nye ord (som i NOiD) er $34 \%$.

Der udtrykkes ikke megen glæde ved ordene, det er politikernes og mediernes sprog som fremhæves som negativt. Kun to eksempler blandt alle disse forslag er indsendt fordi de er gode. Det ene er oldschool: "et præcist ord for noget som er "out", hvilket sker lynhurtigt i dag, det er også et lidt sjovt ord, som man hører af og til", argumenterer forslagsstilleren. Det andet er droneforceldre som får følgende ord med på vejen: "Ordet anser jeg for en værdig afløser for de tidligere curling- eller helikopterforceldre".

Der er to typer indsendere, de ganske almindelige daglige lyttere til programmet og en række skoleklasser som har været i sproglig aktivitet i forbindelse med kåringen. De unge har indsendt: akavet, ebola, fiskesnask,

${ }^{2}$ Ordet opstod i dagene efter Anders Breiviks myrderier på Utøya 22. juli 2011 hvor der blev arrangeret optog med roser over hele landet.

${ }^{3}$ At nave, naving er dannet til institutionen Nav 'Ny Arbeids- og Velferdsforvaltning', en norsk myndighed dannet ved at arbejdsløshedskasse, arbejdsformidling og kommunernes socialtjeneste blev slået sammen i 2006. Der er et NAV-kontor i hver kommune i Norge. Ordet betyder 'at få bidrag, eller slå plat på statens regning'.

${ }^{4}$ Tv-programmer som filmer minut for minut en længerevarende begivenhed. Foreløbig har man fx disse: VM i skak, Bergensbanen minut for minut, og Norsk tv planlægger flere.

${ }^{5}$ Svarer til syrienskriger på dansk. 
forrudet $\phi s, G$ 'gangster', kodylt, lurendrejer, musikmatros, røvfirkant, trøffelgris, twerkdronning, tøffelhelt, voldssprødt - det er ikke til at gennemskue hvorfor disse er bragt i forslag, men fælles er det dog at de ikke som de voksne indsendere belaster ordene med negative konnotationer.

Årets ord blev udvalgt mellem 12 ord som dommerne på forhånd havde indskrænket det store felt til: byhave, digital borger, ebola, girafgate, hverdagssexisme, inklusion, konkurrencestat, madspild, MobilePay, nфdløgn, regnbueaktivist, retcenke, vinderordet blev - tadadada - navnet på appen MobilePay fra Danske Bank. Appen gør det muligt at overføre penge til andre via mobiltelefonen.

Sprognævnet har som tidligere år lavet en liste over de nye ord som er dukket op eller slået igennem i årets løb. Den kan ses på nævnets hjemmeside på denne adresse: http://www.dsn.dk/nyt/nyheder/nyordsliste-2014. Den er udarbejdet af nævnets nyordsgruppe som består af Margrethe Heidemann Andersen, Jørgen Nørby Jensen og mig selv. Her finder man beskrevet forskellige ord fra bikinibro, bikinibridge (2014) 'skønhedsideal hvor piger stræber efter at være så tynde at bikinitrusserne kun hviler på hoftebenene således at der dannes et mellemrum mellem bikinien og den nedre del af maven' over normcore (2014) 'mode der går ud på at være så almindelig som muligt' til skraldetragt (2014, med sporadisk brug fra 2011) 'skraldespand med stor åbning som er placeret i en bils vindueshøjde'. De fleste af ordene kommer også med i NOiD.

\section{LITTERATURHENVISNINGER}

Jarvad, P. (1995). Nye ord - hvorfor og hvordan? København: Gyldendal.

Jensen, J. V. (1906). Digte.

Krone, S., Walther, H. (red.) (2001). Wörter die Geschichte machten. Schlüsselbegriffe des 20. Jahrhunderts. Gütersloh; München: Bertelsmann-Lexikon-Verlag

Meyer, L. (1924). Meyers Fremmedordbog med bidrag ved J.P.F.D. Dahl og F.V. Dahl. 8. udgave. København: Gyldendal.

Mål \& Moele. Tidsskrift.

NDO = Nudansk Ordbog. (2011). København: Politikens Forlag.

Nordsjælland 2.9.2015.

Politiken, 28.8.1981.

$R O=$ Dansk Sprognævn: Retskrivningsordbogen. København: 1996.

Skafte Jensen, E.(2014a). Bred ymer. I: Jyllands-Posten, 26. juni 2014.

Skafte Jensen, E.(2014b). Bred ymer - igen. I: Jyllands-Posten, 16. august 2014.

Skafte Jensen, E.(2014c). Bred ymer - igen - igen. I: Jyllands-Posten, 6. september 2014.

\section{INTERNETKILDER}

$D D N=$ Den Danske Netordbog: http://www.ordbogen.com [adgang: 30.09.2016]

$D D O=$ Den Danske Ordbog: http://ordnet.dk/ddo [adgang: 30.09.2016]

Infomedia = Onlinesøgning i danske medier: http://infomedia.dk/ [adgang: 30.09.2016] 
NOiD = Nye Ord $i$ Dansk — fra 1955 til i dag: http://www.dsn.dk/noid [adgang: 30.09.2016] $O D S=$ Ordbog over det Danske Sprog: http://ordnet.dk/ods [adgang: 30.09.2016]

ODS.S = Ordbog over det Danske Sprogs Supplement: http://ordnet.dk/ods [adgang: 30.09.2016]

\section{Pia Jarvad}

Dansk Sprognævn

Worsaaesvej 19, 4. sal

1972 Frederiksberg C

Denmark

jarvad@dsn.dk 
